$$
\text { D०E/ER/60358- TI }
$$

DOE/ER/60358--T1

DE92 005587

\title{
$=P^{2}$ \\ FINAL REPORT FOR DOE 11/60358 GRANT TO E.R. SHOLKOVITZ AND H.D. LIVINGSTON
}

\section{THE OCEANIC GEOCHEMISTRY OF ARTIFICIAL RADIONUCLIDES: THE "SEEP" PROJECT}

\section{DISCLAIMER}

This report was prepareci as an account of work sponsored by an agency of the United States Government. Neither the United States Government nor any agency thereof, nor any 0 : their employees, makes any warranty, express or implied, or assumes any legal liability or responsibility for the accuracy, completeness, or usefulness of any information, apparatus, product, or process disclosed, or represents that its use would not infringe privately owned rights. Reference herein to any specific commercial product, process, or service by trade name, trademark, manufacturer, or otherwise does not necessarily constitute or imply its endorsement, recommendation, or favoring by the United States Government or any agency thereof. The views and opinions of authors expressed herein do not necessarily state or reflect those of the United States Government or any agency thereof.

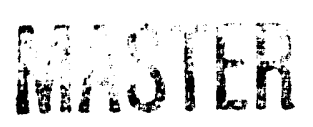




\section{INTRODUCTION AND OBJECTIVES}

Radionuclides have been and continue to be introduced to the marine environinent in various ways. The atmospheric testing of nuclear weapons in the 1960 s resulting in global fallout has been the major contributor of artificial radionuclides to the environment. Nuclear power plants have produced a large quantity of radioactive wastes which are presently being stored on land. The United States, amongst other countries (e.g., England, France, Japan), was seriously investigating the possibility of disposing of these radioactive wastes in the ocean. Clearly it is important to study and to understand the oceanographic behavior of radioactive substances. The DoE sponsored SEEP research, discussed here, is a detailed study into the biogeochemistry of radionuclides in the shelf and slope environment. The questions asked by this research (see below) pertain directly to problems arising from the introduction of radionuclides into the oceans from energy-related industries (e.g. nuclear power plants, waste disposal).

By biogeochemical behavior we mean those biological and geochemical processes that control the concentration, distribution, fluxes, and speciation of radionuclides in the ocean. These processes are complex, vary in both time and space, and may be interrelated. Questions basic to this study are:

1. Once introduced to the oceans, how fast and by what processes are various radionuclides removed from the water column?

2. How does biological activity and adsorption onto suspended particles and sediments relate to $1 ?$

3. What is the distribution between dissolved and suspended phases in the water column for various radionuclides?

4. Are there post-depositional reactions in sediments which will alter the solubility and mobility of radionuclides? In particular, does the degradation of organic matter and development of suboxic and anoxic conditions influence their sedimentary behavior and, if so, at what time and space scales?

5. What are the sediment inventories of various radionuclides in different oceanic environments?

To arrive at answers to the above questions, we have chosen to study artificial radionuclides derived from global fallout--these include ${ }^{137} \mathrm{Cs},{ }^{90} \mathrm{Sr}, 239,240 \mathrm{PL}$ and ${ }^{241} \mathrm{Am}$. Because of their long half lives and involvement with biota, these radionuclides have received much investigation. We have also measured $210 \mathrm{~Pb}$ and $234 \mathrm{Th}$ in our sediment studies as these two natural radionuclides are 
valuable indicators of sediment mixing and depositional rates. These nuclides have also been used as analogues to $\mathrm{Pu}$ in both water column and sediment studies. It is not at all certain that the marine chemistry of ${ }^{210} \mathrm{~Pb}$ and Th isotopes is similar to Pu. Our data will address this point.

"SEEP" is the acronym for Shelf Edge Exchange Erocesses and is a project involving DoE supported scientists from Woods Hole Oceanographic Institution (WHOI), Lamont, Yale and Brookhaven. One objective of SEEP is to study the biogeochemistry of natural and artificial radionuclides in the shelf and slope environment off the east coast of the United States. The shelf and slope environment is a particularly interesting place to undertake this type of study because it is characterized by:

1. greater biological productivity relative to the open ocean

2. the presence of relatively high suspended particle concentrations

3. greater influence of the sediment on the water column chemistry

4. a transition in sedimentary redox conditions from anoxic to more oxic with increasing depth

5. the possibility of enhanced radionuclide removal at oceanic margins

\section{SPECIFIC OBJECTIVES}

\section{A. Water Column}

The purpose of these transuranic studies was 1) to determine the nature of fallout transuranic transport in, and removal from, waters of the northeast U.S. continental margin aris 2) to use this information to develop a predictive capability of the processes which would act on energy related pollutants (especially those with properties favoring association with particles) which are potentially likely to impact this oceanic region. The two transuranic elements studied, Pu and Am, represent a contrast in particle reactivities and thus serve to model a corresponding range of reactive pollutant behavior. The latter, as ${ }^{241} \mathrm{Am}$ ( $\mathrm{T} 1 / 2-433$ years), is produced in the oceans by decay in-situ from its ${ }^{241} \mathrm{Pu}$ (T $1 / 2$. 14.4 years) parent; its goechemical behavior is controlled by particle association constants generally higher than those of Pu by approximately an order of magnitude. The longer lived $\mathrm{Pu}$ isotopes, ${ }^{239} \mathrm{Pu}$ and $240 \mathrm{Pu}$ ( ${ }^{\mathrm{T}} 1 / 2-24,000$ and 6,570 years) appear to exhibit substantially longer oceanic residence times than Am and hence are relatively more affected by the dynamics of oceanic circulation processes.

\section{B. Sediments}

The main objective of this research is to use pere water chemistry to quantify the extent to which $239,240 \mathrm{Pu}$ and ${ }^{137} \mathrm{Cs}$ undergo post-depositional (i.e. diagenetic) reactions in different types of shelf and slope sediments. Redox state, organic matter content and rates of sedimentation and mixing are 
important variables in controlling the diagenetic mobility of radionuclides. As our results will demonstrate, the SEEP I transect provides a range of sediment conditions to study the diagenetic chemistries of radionuclides.

High precision mass spectrometric measurements of $240 \mathrm{Pu} / 239 \mathrm{Pu}$ ratios in waters, sediments, pore waters, and suspended particles have allowed the sources, sinks and oceanic reactivity of plutonium to be determined in a manner not feasible by only measuring the concentration of plutonium.

\section{SUMMARY}

The research has been reported in four papers published in scientific journals and in the Ph.D. thesis of K.O. Buesseler, all of which are listed below.

1. Buesseler, K.O., H.D. Livingston and E.R. Sholkovitz (1985/1986). ${ }^{239}, 240 \mathrm{Pu}$ and excess $210 \mathrm{~Pb}$ inventories along the shelf and slope of the Northeast U.S.A. Earth Planet Sci. Lett., 86, 10-22.

2. Buesseler, K.O. and E.R. Sholkovitz (1987). The geochemistry of fallout plutonium in the North Atlantic: I. A pore water study in shelf, slope and deep-sea sediments. Geochim. Cosmochim. Acta, 51, 2605-2622.

3. Buesseler, K.O. and E.R. Sholkovitz (1987). The geochemistry of fallout plutonium in the North Atlantic: $11 .{ }^{240} \mathrm{Pu} /{ }^{239} \mathrm{Pu}$ ratios and their significance. Geochim. Cosmochim. Acta, 51, 26232637.

4. Anderson, R.F., R.F. Bopp, K.O. Buesseler and P.E. Biscaye (1988). Mixing of particles and organic constituents in sediments from the continental sheff and slope4 off Cape Cod: SEEP 1 - results. Continental Shelf Res., 8, 925-946.

5. Buesseler, K.O. (1986). Plutonium isotopes in the North Atlantic. Ph.D. thesis. WHOIMIT Joint Program in Oceanography, $220 \mathrm{pg}$.

The results of this research are best summarized for this report by including the abstracts of the above cited papers. These follow below.

$239240 \mathrm{PU}$ and excess $210 \mathrm{~Pb}$ inventories along the shelf and slope of the northeast U.S.A. 
Sedimentary $\mathrm{Pu}$ and excess ${ }^{210} \mathrm{~Pb}$ inventory data are examined from a large number of sites along the U.S. North Atlantic shelf and slope. From these data, an estimate can be made of the magnitude and location of $\mathrm{Pu}$ and $210 \mathrm{~Pb}$ accumulation in this region. A major feature of the data is a decrease in the $\mathrm{Pu}$ and $210 \mathrm{~Pb}$ inventories with water depth, which appears to reflect a decrease in the net scavenging of these elements off-shore. When $\mathrm{Pu}$ and $210 \mathrm{~Pb}$ inventories are summed over water depths less than $4000 \mathrm{~m}$ in the North Atlantic shelf and slope region, the sediments can account for $24 \pm$ $8 \%$ of the expected $\mathrm{Pu}$ and $83 \pm 15 \%$ of the expected ${ }^{210} \mathrm{~Pb}$ inputs. Ai water depths greater than 4000 $m$ in this region, we find a greater deficiency in the measured inventories of both ${ }^{210} \mathrm{~Pb}$ and $\mathrm{Pu}$, which cannot be accounted for in the shallower sediments. This suggests that the northwest Atlantic continental margin is not a major site of $\mathrm{Pu}$ and $210 \mathrm{~Pb}$ removal and storage, when compared to atmospheric, in situ, and lateral inputs of these radionuclides.

\section{The geochemistry of fallout plutenium in the North Atlantic: A A pore water study in shelf slope and deep-sea sediments}

The distribution of fallout plutonium between pore waters and sediments in the Northwest Atlantic is examined in order better to define the potential for Pu migration from and within marine sediments. Along a transect of seven coriss collecied between Woods Hole and Bermuda, the solid phase $239,240 \mathrm{Pu},{ }^{210} \mathrm{~Pb}^{\mathrm{eX}}$ and ${ }^{137} \mathrm{Cs}$ results do not suggest that any of these tracers are preferentially mobile within the cores. Pore water $\mathrm{Pu}$ activities appear to be controlled primarily by the distribution of $\mathrm{Pu}$ in the solid phase, with an operationally determined distribution coefficient, $K_{d}$ in the range of $0.2-23 \times 10^{4}$. There is a trend in the $K_{d} s$ along the transect, with higher values in the $10^{4}-10^{5}$ range on the shelf and slope, to lower values $<10^{4}$ in the deep-sea cores. The exact mechanism for this shift has yet to be determined. While the Pu pore water activity at the sediment-water interface is elevated over riear bottom water activities, the potential for Pu remobilization out of the sediments is small $\left(0.3-24 \times 10^{-5} \mathrm{dpm}\right.$ $239,240 \mathrm{Pu} / \mathrm{cm}^{2}$ year). Sediment mixing models are not significantly allered by the inclusion of $\mathrm{Pu}$ diffusion terms, since the pore water terms are so small relative to typical sediment mixing rales.

The geechemistry of fallout plutenium in the North Atlantic: $\mathbb{L}^{240} \mathrm{Pu}^{239} \mathrm{Pu}$ ratios and their sianificance 
A systematic decrease in the $240 \mathrm{Pu} /{ }^{239} \mathrm{Pu}$ ratio in marine sediments is found with increasing water depth along a transect of cores between Woods Hole and Bermuda. The ${ }^{240} \mathrm{Pu} /{ }^{239} \mathrm{Pu}$ atom ratios range from $\simeq 0.18$ on the shelf to $\simeq 0.10$ at $5000 \mathrm{~m}$ but do not change with depth in individual cores. A model is presented which can account for the range of ${ }^{240} \mathrm{Pu} /{ }^{239} \mathrm{Pu}$ ratios found in this and other similar studies (NOSHKIN and GATROUSIS, 1974; SCOTT et al., 1983). We propose that there have been at least two distinct sources of fallout $\mathrm{Pu}$ to this region. The major source of $\mathrm{Pu}$ is global stratospheric fallout, characterized by $\mathrm{a}^{240} \mathrm{Pu} /{ }^{239} \mathrm{Pu}$ ratio of 0.18 and a relatively long residence time in seawater. The second source is characterized by a much lower ${ }^{240} \mathrm{Pu} /{ }^{239} \mathrm{Pu}$ ratio, and relative to globai fallout it must have been much more efficiently removed from the water column to deep-sea sediments. We suggest that surface-based low yield testing at the Nevada Test Site is the only source of low ratio fallout Pu which could account for the timing, inventories, and refractory characteristics of this second component of fallout Pu inputs to the North Atlantic.

\section{Mixing of particles and organic constituents in sediments from the continental shelf and slope off Cape Cod: SEEP - I results}

Sediment cores were collected from the continental shelf and slope along the SEEP - - I transect $\left(71^{\circ} \mathrm{W}\right)$ south of New England. Profiles of $210 \mathrm{~Pb}$ and of $239,240 \mathrm{Pu}$ were measured in the cores. Measurable amounts of $\mathrm{Pu}$ and of unsupported ${ }^{210} \mathrm{~Pb}$ occurred to the same depth in every core where both were measured, indicating that the distributions of tracers added to the slope sediments during the past 100 years are controlled by sediment mixing processes. Mixing coefficients of $0.14-1.0 \mathrm{~cm}^{2} \mathrm{y}^{-1}$ were obtained from the ${ }^{2.10} \mathrm{~Pb}$ and $\mathrm{Pu}$ distributions in slope sediments. A sediment mixing model that incorporates these mixing rates and a sedimentation rate of about $0.01 \mathrm{~g} \mathrm{~cm}^{-2} \mathrm{y}^{-1}$ determined from other information predicts the measured distributions of DDT and related compounds in one core from the slope. An upper limit for the deposition of organic carbon in the slope sediments of $2.5 \mathrm{~g} \mathrm{C} \mathrm{m}^{-2} \mathrm{y}^{-1}$ is obtained, significantly lower than earlier estimates. The measured ${ }^{14} \mathrm{C}$ age of surface sediments is greater than predicted from a model for steady-state accumulation of planktonic detritus, suggesting that some of the carbon deposited on the slope is older reworked material, possibly derived from the continent or eroded from other marine deposits. 


\section{CONCLUSIONS AND HIGHLIGHTS}

The research under this DOE grant has made several important observations and interpretations. Pore water measurements of Pu and Cs were innovative and allowed the first direct determination of the mobility of their isotopes in marine sediments. Moreover, the measurement of Pu isotopes gave valuable and new insights into the chemical reactivity, sources and removal of Pu from the oceans. For example, $\mathrm{Pu}$ in global fallout is removed slower than $\mathrm{Pu}$ from close-in land based testing. Combined with $\mathrm{Pb}^{2} 10$ data, the Pu isotopic data from sediment cores also allow more realistic calculations of both the mixing and accumulation rates of sediments. 
